\title{
Supernumerary Teeth in Nepalese Children
}

\author{
Varun Pratap Singh, ${ }^{1}$ Amita Sharma, ${ }^{2}$ and Sonam Sharma ${ }^{3}$ \\ ${ }^{1}$ Department of Orthodontics, College of Dental Sciences, B.P.K.I.H.S., Dharan, Nepal \\ ${ }^{2}$ Department of Dentistry, SHKM Government Medical College, Mewat, Haryana 122107, India \\ ${ }^{3}$ Department of Pathology, SHKM Government Medical College, Mewat, Haryana 122107, India
}

Correspondence should be addressed to Amita Sharma; dramitasharma09@gmail.com

Received 31 July 2014; Revised 10 November 2014; Accepted 15 November 2014; Published 23 November 2014

Academic Editor: Mehmet Ozgur Sayin

Copyright ( 2014 Varun Pratap Singh et al. This is an open access article distributed under the Creative Commons Attribution License, which permits unrestricted use, distribution, and reproduction in any medium, provided the original work is properly cited.

\begin{abstract}
Objective. The objectives of the present study were to investigate the prevalence and characteristics of supernumerary teeth in a patient sample of Nepalese children. Study Design. A survey was performed on 2684 patients (1829 females and 1035 males) ranging in age from 6 to 14 for the presence of supernumerary teeth. For each patient with supernumerary teeth the demographic variables (age and sex), number, location, eruption status, and morphology were recorded. Descriptive statistics were performed. Results. Supernumerary teeth were detected in 46 subjects (1.6\%), of which 26 were males and 20 were females with a male : female ratio of $1.3: 1$. The most commonly found supernumerary tooth was mesiodens followed by maxillary premolars, maxillary lateral incisor, and mandibular lateral incisor. Of the 55 supernumerary teeth examined, 58.18\% $(n=32)$ had conical morphology, followed by tuberculate $(30.90 \%, n=17)$ and supplemental $(10.90 \%, n=6)$ forms. The majority of the supernumerary teeth were erupted $(56.36 \%, n=31)$. Conclusion. The prevalence of supernumerary teeth in Nepalese children was found to be $1.6 \%$, the most frequent type being mesiodens. Conical morphology was found to be the most common form of supernumerary tooth.
\end{abstract}

\section{Introduction}

Supernumerary teeth may be defined as teeth in excess of the usual configuration of twenty deciduous and thirty-two permanent teeth [1]. Their reported prevalence ranges between 0.3 and $0.8 \%$ in the primary dentition and 0.1 and $3.8 \%$ in the permanent dentition. Supernumerary tooth does not show any sexual predilection in the deciduous dentition. However, twice as many males are affected as compared to females in the permanent dentition [2-5]. The supernumerary tooth may show isolated occurrence or may be multiple, maybe unilateral or bilateral, erupted, or impacted, and can occur in either or both the jaws. Multiple supernumerary teeth are rare and are usually seen in association with cleft lip/palate, cleidocranial dysplasias, Gardner's syndrome, and so forth [6].

The exact etiology of supernumerary teeth is unknown; however, several theories have been postulated to explain their presence. The phylogenetic theory as a regression to the anthropoids whose dentition had more teeth, the autonomic recessive inheritance or linkage to the $\mathrm{x}$ chromosome, an abnormal reaction to a local traumatic episode, environmental factors, dichotomy of the tooth germ, and the theory of hyperactivity of the dental lamina are the most accepted ones [7].

Supernumerary teeth can be classified according to their location and morphology. The most frequent location is the maxilla, of which the mesiodens (anterior maxillary medial region) is the most commonly observed supernumerary tooth. Based on morphology, they can be classified as conical, tuberculate, supplemental, and odontomas [8, 9]. Clinically, supernumerary teeth can cause various problems locally such as retention of the primary tooth, delayed/failure of eruption of the permanent tooth, ectopic eruptions, tooth displacements, follicular/dentigerous cysts, and other alterations which require surgical or orthodontic intervention $[10,11]$.

The objective of the present study was to investigate the prevalence and characteristics of supernumerary teeth in the Nepalese population which is the first study of its kind in Nepal. 


\section{Materials and Methods}

A survey was performed on 2864 patients (1829 females and 1035 males) ranging in age from 6 to 14 years attending the Department of Orthodontics, College of Dental Surgery, BP Koirala Institute of Health Sciences, Dharan, Nepal, over a period of two years from January 2010 to February 2012 for the presence of supernumerary teeth. This study was approved by institutional ethical review board and guidelines from the Helsinki declaration were followed. Informed consent was taken from the parents of the subjects. The patients with any syndrome or congenital anomalies such as cleft lip/palate were not included in the study. For each patient with supernumerary teeth, the demographic variables (age and sex), number, location, eruption status, and morphology of supernumerary tooth were recorded. Descriptive statistics were performed and results were tabulated.

\section{Results}

Supernumerary teeth were detected in 46 subjects (1.60\%), of which 26 were males and 20 were females with male female ratio of $1.3: 1$ (Table 1 ).

Table 2 shows the characteristics of supernumerary teeth. In $82.60 \%(n=38)$ of cases, one supernumerary tooth was observed, in $15.21 \%(n=7)$ two supernumerary teeth were observed, and three supernumerary teeth were observed in one patient only $(n=1,2.17 \%)$. A total of 55 supernumerary teeth were observed, of which $98.18 \%(n=54)$ were located in the maxillary arch, while $1.81 \%(n=1)$ were found in the mandible. The most commonly found supernumerary tooth was mesiodens (63.63\%) followed by maxillary lateral incisor $(25.45 \%)$ and maxillary first premolar (10.90\%). Conical morphology was seen in $58.18 \%(n=32)$ (Figure 1), while $30.90 \%(n=17)$ were tuberculate (Figure 2$)$ and $10.90 \%$ $(n=6)$ were supplemental (Figure 3) in form. Regarding their eruption status, $56.36 \%(n=31)$ had erupted and $46.63 \%(n=24)$ were impacted.

\section{Discussion}

Supernumerary teeth are developmental alterations that may manifest in both primary and permanent dentition, may be seen in both maxilla and mandible, and can involve any tooth. They may be associated with a syndrome or can be found in nonsyndromic patients also [21]. In our study, the prevalence of supernumerary teeth in nonsyndromic cases was found to be $1.60 \%$ and showed male predilection with a male: female ratio of $1.3: 1$.

Table 3 provides an overview of studies done on supernumerary teeth in different populations. It can be observed that the prevalence of supernumerary teeth in the Nepalese population is similar to that of Hungarian [12], Swedish [16], and Brazilian [19] population. The male: female ratio was in accordance with the studies of Gábris et al. [12] in Hungarian population, Brook [17] in British population, and Küchler et al. in Brazilian population [18]. However other studies have reported that males are affected approximately twice as frequently as females in permanent dentition $[2,13-15,20]$.

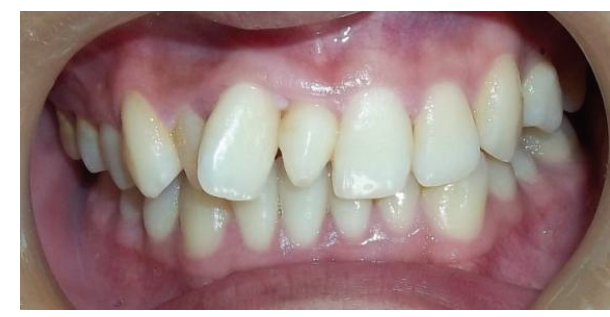

FIGURE 1: Intraoral photograph showing conical mesiodens.

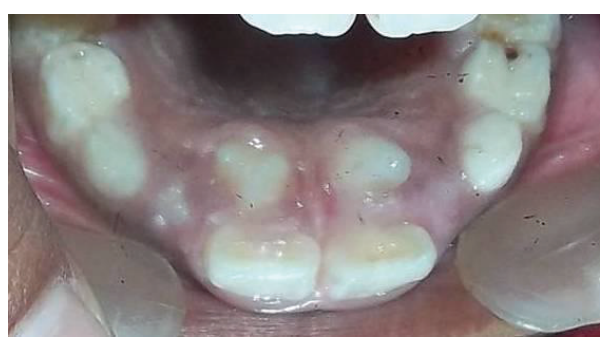

FIGURE 2: Intraoral photograph showing palatally erupted paired tuberculate supernumerary teeth.

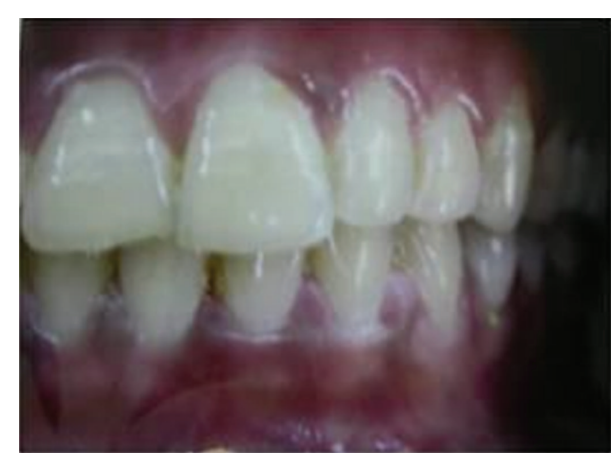

FIGURE 3: Intraoral photograph showing maxillary left supplemental lateral incisor.

These differences may be due to the differences in methodology employed and due to racial and ethnic differences in various populations [5].

In accordance with other reported studies, $82.60 \%(n=$ 38) of the supernumerary teeth were found to be single, $15.21 \%(n=7)$ were paired, and only one case showed triple supernumerary teeth $[2,22]$. Also, $98.8 \%(n=33)$ of the supernumerary teeth were found to be in the maxillary arch. This value is high as compared to Salcido-García et al. [23] who found $66 \%$ of supernumerary teeth in the maxillary arch. However, it is in accordance with Simoes et al. [19] and de Oliveira Gomes et al. [11] who reported $96.7 \%$ and $91.3 \%$ of the cases in maxilla, respectively. The most commonly found supernumerary tooth has been reported to be mesiodens $[19,20,23-25]$, which coincides with our findings. In order of decreasing frequency, some authors consider that mesiodens are followed by distomolars [25, 26], but others [21, 23] found that mesiodens are followed by lateral incisors and premolars. Our findings are in accordance with the latter, the mesiodens being most prevalent followed by lateral 
TABLE 1: The prevalence and distribution of supernumerary teeth in males and females.

\begin{tabular}{lcccccc}
\hline Gender & Number & Supernumerary teeth & Frequency (\%) & $X^{2}$ value & $P$ value & Total (\%) \\
\hline Female & 1829 & 20 & $1.09 \%$ & 8.11 & 0.0043 & $46(1.60 \%)$ \\
Male & 1035 & 26 & $2.51 \%$ & & \\
\hline
\end{tabular}

TABLE 2: Summary of the characteristics of supernumerary teeth.

\begin{tabular}{|c|c|c|c|c|}
\hline \multicolumn{3}{|c|}{ Supernumerary teeth characteristics } & \multirow{2}{*}{$\frac{\text { Number }(\text { total }=55)}{38}$} & \multirow{2}{*}{$\frac{\text { Percentage }(\%)}{82.60}$} \\
\hline \multirow{3}{*}{ Number } & & Single & & \\
\hline & & Double & 7 & 15.21 \\
\hline & & Triple & 1 & 2.17 \\
\hline \multirow{5}{*}{ Location } & Maxilla $(n=54)$ & Mesiodens & 35 & $64.81 \%$ \\
\hline & $98.18 \%$ & Lateral incisor & 13 & $24.07 \%$ \\
\hline & & Maxillary premolar & 6 & $11.11 \%$ \\
\hline & Mandible $(n=1)$ & Lateral incisor & 1 & - \\
\hline & $1.81 \%$ & & & \\
\hline \multirow{2}{*}{ Eruption Status } & & Impacted & 24 & 43.63 \\
\hline & & Erupted & 31 & 56.36 \\
\hline \multirow{3}{*}{ Morphology } & & Conical & 32 & 58.18 \\
\hline & & Tuberculate & 17 & 30.90 \\
\hline & & Supplemental & 6 & 10.90 \\
\hline
\end{tabular}

TABLE 3: Summary of various studies carried out on supernumerary teeth in different populations.

\begin{tabular}{|c|c|c|c|c|c|c|}
\hline Authors & Sample size & Country & Age & Method & Prevalence & $\begin{array}{l}\text { Male : female } \\
\text { ratio }\end{array}$ \\
\hline Present study & 2864 & Nepal & $6-14$ years & $\begin{array}{l}\text { Clinical } \\
\text { examination and } \\
\text { radiographs }\end{array}$ & $1.60 \%$ & $1.3: 1$ \\
\hline $\begin{array}{l}\text { Gábris et al. (2006) } \\
{[12]}\end{array}$ & 2219 & Hungary & 15-20 years & Radiographs & $1.53 \%$ & $1.4: 1$ \\
\hline $\begin{array}{l}\text { Tyrologou et al. } \\
\text { (2005) [13] }\end{array}$ & $\begin{array}{l}97 \text { children with } \\
\text { mesiodens }\end{array}$ & Sweden & $3-15$ years & $\begin{array}{l}\text { Clinical } \\
\text { examination and } \\
\text { radiographs }\end{array}$ & - & $2: 1$ \\
\hline $\begin{array}{l}\text { Rajab and } \\
\text { Hamdan (2002) } \\
{[2]}\end{array}$ & 152 & Jordan & $5-15$ years & $\begin{array}{l}\text { Clinical } \\
\text { examination and } \\
\text { radiographs }\end{array}$ & - & $2.2: 1$ \\
\hline Liu (1995) [14] & $\begin{array}{c}112 \text { (premaxillary } \\
\text { region) }\end{array}$ & Taiwan & 4-14 years & $\begin{array}{l}\text { Clinical } \\
\text { examination and } \\
\text { radiographs }\end{array}$ & - & $2.8: 1$ \\
\hline von Arx (1992) [15] & $\begin{array}{l}90 \text { (anterior } \\
\text { maxilla) }\end{array}$ & Switzerland & $6-10$ years & $\begin{array}{l}\text { Clinical } \\
\text { examination and } \\
\text { radiographs }\end{array}$ & - & $2.6: 1$ \\
\hline $\begin{array}{l}\text { Bodin et al. } \\
\text { [16] }\end{array}$ & 21,609 & Sweden & - & - & $1.6 \%$ & $1.7: 1$ \\
\hline Brook (1974) [17] & 1331 & $\begin{array}{l}\text { United } \\
\text { Kingdom }\end{array}$ & 11-14 years & $\begin{array}{l}\text { Clinical } \\
\text { examination and } \\
\text { radiographs }\end{array}$ & $2.1 \%$ & $1.4: 1$ \\
\hline Yusof (1990) [3] & 48,550 & USA & $\begin{array}{c}\text { Average } 40 \\
\text { years }\end{array}$ & Radiographs & $0.91 \%$ & - \\
\hline $\begin{array}{l}\text { Küchler et al. } \\
\text { (2011) [18] }\end{array}$ & 1166 & Brazil & $6-12$ years & $\begin{array}{l}\text { Clinical } \\
\text { examination and } \\
\text { radiographs }\end{array}$ & $2.3 \%$ & $1.45: 1$ \\
\hline $\begin{array}{l}\text { Simoes et al. (2011) } \\
{[19]}\end{array}$ & 1719 & Brazil & $4-14.5$ years & Radiographs & $1.7 \%$ & - \\
\hline $\begin{array}{l}\text { Celikoglu et al. } \\
(2010)[20]\end{array}$ & 3491 & Turkey & $12-25$ years & Radiographs & $1.2 \%$ & $1.8: 1$ \\
\hline
\end{tabular}


incisors and premolars. However, we were unable to find supernumerary canines and molars which may be because of the lower incidence of such teeth and further due to late developing supernumeraries [27]. In terms of morphology, conical form was most common followed by tuberculate and supplemental forms which was in agreement with the findings of other researchers $[2,11,14,18]$. When assessing eruption status, it was found that $56.36 \%(n=31)$ of the supernumerary teeth were erupted. This finding depicts a higher rate of eruption frequency than that reported by other authors [2, 11, 15, 27]. Liu [14] and de Oliveira Gomes et al. [11] showed that eumorphic teeth had a higher frequency of eruption, whereas in our study there was no significant relation between morphology of supernumerary tooth and their eruption status.

\section{Conclusion}

The prevalence of supernumerary teeth in Nepalese patients was found to be $1.60 \%$. Males were affected more commonly than the females. The supernumerary teeth occurred more frequently in the maxilla as compared to the mandible with mesiodens being the most common type. Morphologically, conical type was the most prevalent. The majority of the supernumerary teeth were erupted.

\section{Conflict of Interests}

The authors declare that there is no conflict of interests regarding the publication of this paper.

\section{References}

[1] C. Schulze, "Developmental abnormalities of the teeth and jaws," in Thoma's Oral Pathology, R. J. Gorlin and H. M. Goldman, Eds., pp. 112-122, CV Mosby, St. Louis, Miss, USA, 1970.

[2] L. D. Rajab and M. A. M. Hamdan, "Supernumerary teeth: review of the literature and a survey of 152 cases," International Journal of Paediatric Dentistry, vol. 12, no. 4, pp. 244-254, 2002.

[3] W. Z. Yusof, "Non-syndrome multiple supernumerary teeth: literature review," Journal of the Canadian Dental Association, vol. 56, no. 2, pp. 147-149, 1990.

[4] E. C. Stafne, "Supernumerary teeth," Dental Cosmos, vol. 74, pp. 653-659, 1932.

[5] M. A. Scheiner and W. J. Sampson, "Supernumerary teeth: a review of the literature and four case reports," Australian Dental Journal, vol. 42, no. 3, pp. 160-165, 1997.

[6] M. Vichi and L. Franchi, "Abnormalities of the maxillary incisors in children with cleft lip and palate," ASDC Journal of Dentistry for Children, vol. 62, no. 6, pp. 412-417, 1995.

[7] P. V. Rao and M. M. Chidzonga, "Supernumerary teeth: literature review," The Central African Journal of Medicine, vol. 47, no. 1, pp. 22-26, 2001.

[8] L. Mitchell, An Introduction to Orthodontics, Oxford University Press, 1st edition, 1996.

[9] R. J. Andlaw and W. P. Rock, A Manual of Paediatric Dentistry, Churchill Livingstone, New York, NY, USA, 4th edition, 1996.

[10] Y. Zilberman, M. Malron, and A. Shteyer, "Assessment of 100 children in Jerusalem with supernumerary teeth in the premaxillary region," ASDC Journal of Dentistry for Children, vol. 59, no. 1, pp. 44-47, 1992.

[11] C. de Oliveira Gomes, S. N. Drummond, B. C. Jham, E. N. Abdo, and R. A. Mesquita, "A survey of 460 supernumerary teeth in Brazilian children and adolescents," International Journal of Paediatric Dentistry, vol. 18, no. 2, pp. 98-106, 2008.

[12] K. Gábris, G. Fábián, M. Kaán, N. Rózsa, and I. Tarján, "Prevalence of hypodontia and hyperdontia in paedodontic and orthodontic patients in Budapest," Community Dental Health, vol. 23, no. 2, pp. 80-82, 2006.

[13] S. Tyrologou, G. Koch, and J. Kurol, "Location, complications and treatment of mesiodentes-a retrospective study in children," Swedish Dental Journal, vol. 29, no. 1, pp. 1-9, 2005.

[14] J. F. Liu, "Characteristics of premaxillary supernumerary teeth: a survey of 112 cases," ASDC Journal of Dentistry for Children, vol. 62, no. 4, pp. 262-265, 1995.

[15] T. von Arx, "Anterior maxillary supernumerary teeth: a clinical and radiographic study.", Australian Dental Journal, vol. 37, no. 3, pp. 189-195, 1992.

[16] I. Bodin, P. Julin, and M. Thomsson, "Hyperodontia. I. Frequency and distribution of supernumerary teeth among 21,609 patients," Dentomaxillofacial Radiology, vol. 7, no. 1, pp. 15-17, 1978.

[17] A. H. Brook, "Dental anomalies of number, form and size: their prevalence in British schoolchildren," Journal of the International Association of Dentistry for Children, vol. 5, no. 2, pp. 3753, 1974.

[18] E. C. Küchler, A. G. da Costa, M. D. C. Costa, A. R. Vieira, and J. M. Granjeiro, "Supernumerary teeth vary depending on gender," Brazilian Oral Research, vol. 25, no. 1, pp. 76-79, 2011.

[19] F. X. P. C. Simoes, I. Crusoe-Rebello, F. S. Neves, C. OliveiraSantos, A. L. Ciamponi, and O. G. da Silva Filho, "Prevalence of supernumerary teeth in orthodontic patients from South western Brazil," International Journal of Odontostomatology, vol. 5, no. 2, pp. 199-202, 2011.

[20] M. Celikoglu, H. Kamak, and H. Oktay, "Prevalence and characteristics of supernumerary teeth in a non-syndrome Turkish population: associated pathologies and proposed treatment," Medicina Oral, Patologia Oral y Cirugia Bucal, vol. 15, no. 4, pp. e575-e578, 2010.

[21] M. I. Leco Berrocal, J. F. Martín Morales, and J. M. Martínez González, "An observational study of the frequency of supernumerary teeth in a population of 2000 patients," Medicina Oral, Patología Oral y Cirugía Bucal, vol. 12, no. 2, pp. E134-E138, 2007.

[22] F. Tay, A. Pang, and S. Yuen, "Unerupted maxillary anterior supernumerary teeth: report of 204 cases," ASDC Journal of Dentistry for Children, vol. 51, no. 4, pp. 289-294, 1984.

[23] J. F. Salcido-García, C. Ledesma-Montes, F. Hernández-Flores, D. Pérez, and M. Garcés-Ortíz, "Frequency of supernumerary teeth in Mexican population," Medicina Oral, Patologia Oral y Cirugia Bucal, vol. 9, no. 5, pp. 406-407, 2004.

[24] E. Ferrés-Padró, J. Prats-Armengol, and E. Ferrés-Amat, “A descriptive study of 113 unerupted supernumerary teeth in 79 pediatric patients in Barcelona," Medicina Oral, Patologia Oral y Cirugia Bucal, vol. 14, no. 3, pp. E146-E152, 2009.

[25] P. Fernández Montenegro, E. Valmaseda Castellón, L. Berini Aytés, and C. Gay Escoda, "Retrospective study of 145 supernumerary teeth," Medicina Oral Patologia Oral y Cirugia Bucal, vol. 11, no. 4, pp. E339-E344, 2006. 
[26] V. Menardía-Pejuan, L. Berini-Aytés, and C. Gay-Escoda, "Supernumerary molars. A review of 53 cases," Bulletin $d u$ Groupèment International pour la Recherche Scientifique en Stomatologie \& Odontologie, vol. 42, no. 2-3, pp. 101-105, 2000.

[27] S. M. Cochrane, J. R. Clark, and N. P. Hunt, "Late developing supernumerary teeth in the mandible," British Journal of Orthodontics, vol. 24, no. 4, pp. 293-296, 1997. 


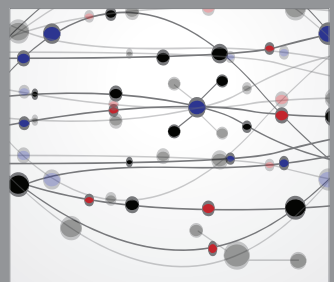

The Scientific World Journal
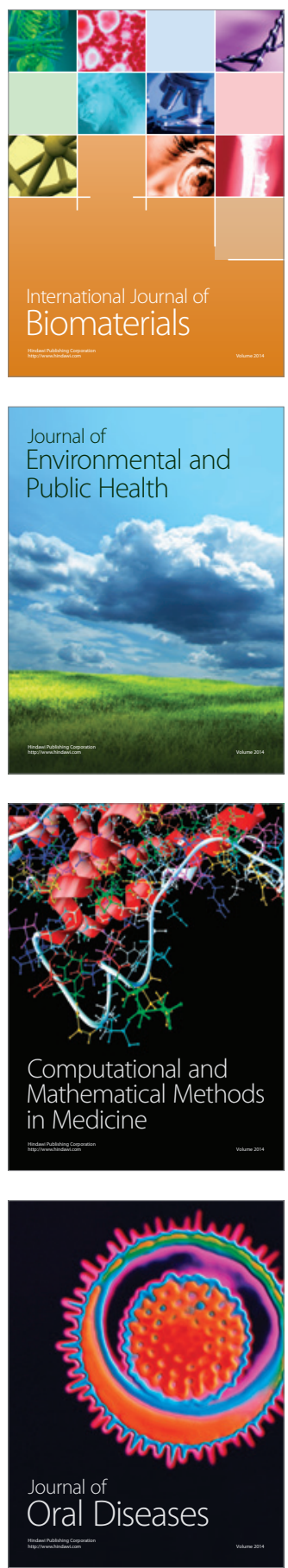
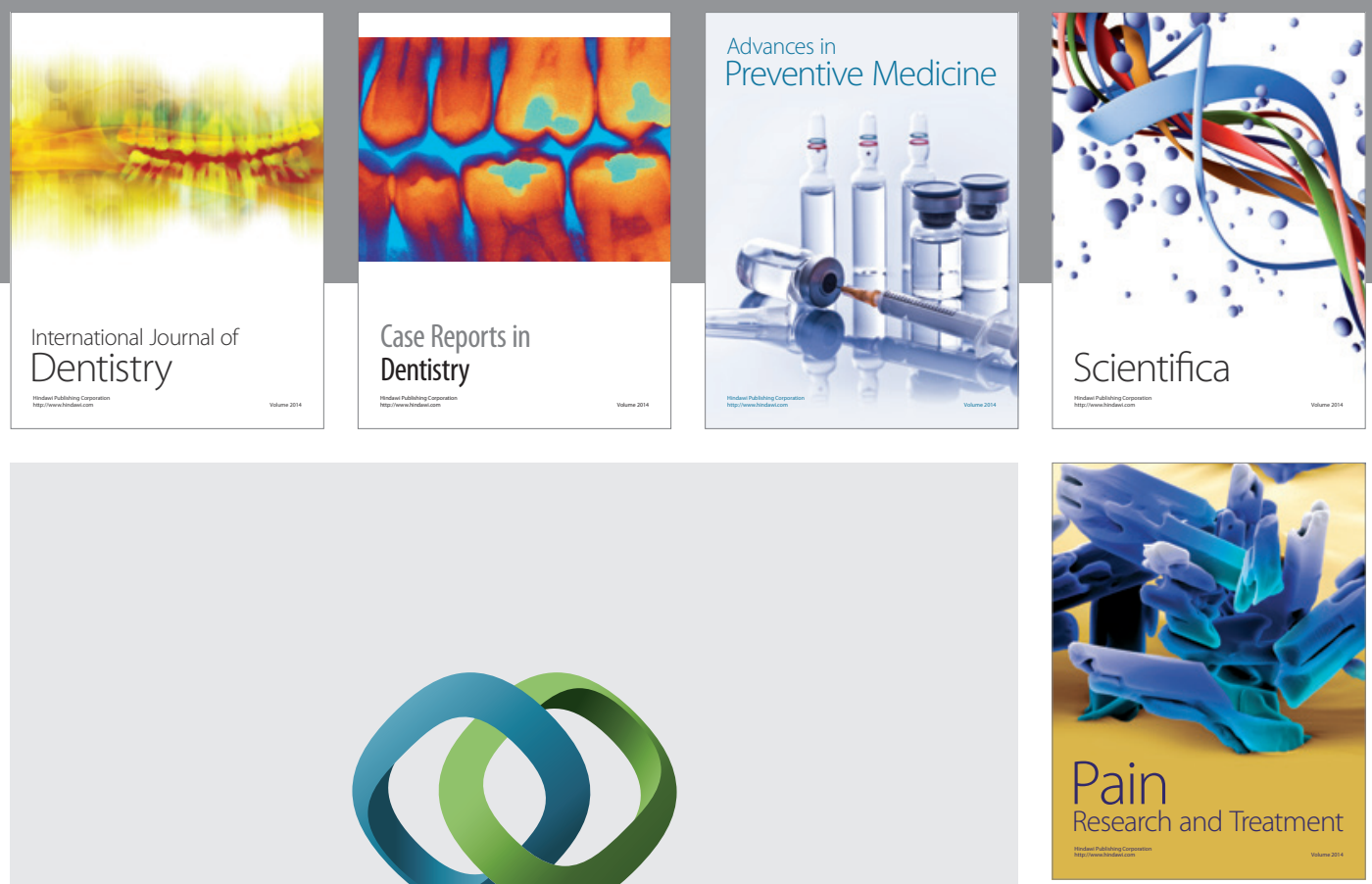

\section{Hindawi}

Submit your manuscripts at

http://www.hindawi.com
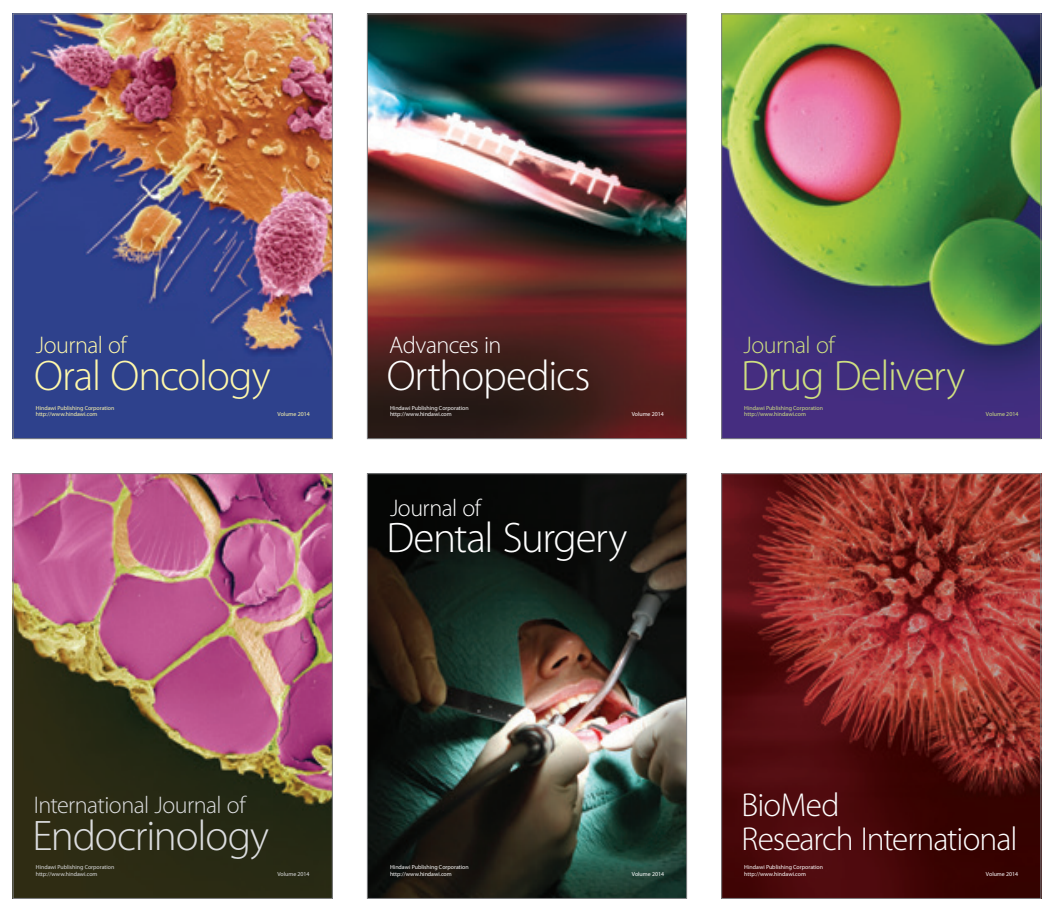

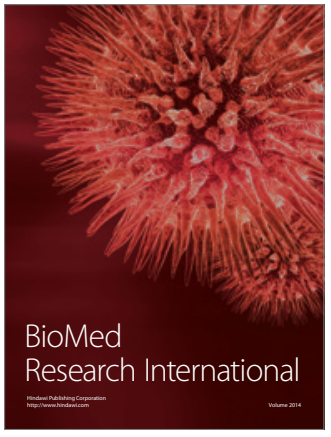

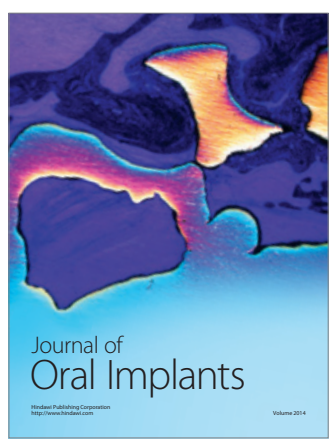
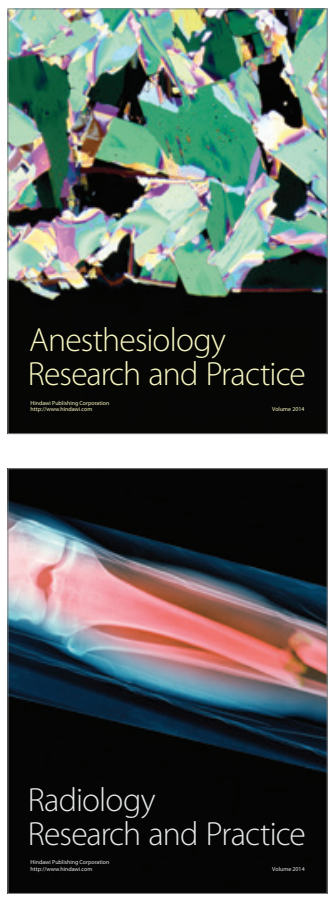